inductive standpoint. The old genius is too strong, and stands menacingly by while he writes. Several text-books have made a bold start with this object in view; but after a brief beginning of little promise, the argument rapidly assumes the old dogmatic form. Substances are said to be aldehydes "because they contain the aldehyde group"; or unsaturated, "because they possess double bonds." At every turn, the chemical and physical properties of compounds are attributed to them as a result of certain "constitutions" or "groupings of the atoms within the molecules." Rarely, if ever, is the veil lifted, and the student permitted to see that, as a matter of fact, precisely the reverse order is the one which should hold, and that it is the physical and chemical properties which determine the constitution. It is a matter of some surprise that we do not hear of compounds with good constitutions, and of others, in pathological conditions perhaps, with bad constitutions. After an explosion of nitroglycerin, it would seem to be quite in keeping to hear that the compound unfortunately had ruined its constitution.

Since this difference of method has grown up within these two divisions of chemistry, it has come to pass that students, thrust suddenly into the field of organic chemistry, find themselves lost in a maze of symbols, formulæ and nomenclature. Since the elementary inorganic course at present has abandoned the use of graphic formulæ almost altogether, the student does not receive any discipline of that part of his mind which, for want of a better name, may be called his formulæcomprehending faculty, and, in consequence, is at a loss to find himself in this unexpected confusion. No assistance is furnished him by the elementary texts of organic chemistry, because these volumes still take it for granted that the student has practised atomic gymnastics of the kind in favor some thirty years ago.

It seems to me that the teaching of elementary organic chemistry must soon undergo a radical change, perhaps a revolution. I believe this advance is developing at the present time. Let us return to the basis of experimental facts and observations, and let us state our theoretical conclusions with these fully in the foreground of our thoughts. There is no difficulty in presenting to the student a set of facts determined by experiment; and there is no impossibility in bringing him to see how these facts may be expressed, in part at least, by properly chosen symbols in terms of certain hypotheses and theories. The modern text-book of organic chemistry remains to be written; it will view the subject from this point of vantage.

In his memorable address before the German Chemical Society on the occasion of the celebration in his honor, held in 1890, Kekulé gave the well-known account of the origin of the theory of the benzene ring, and at the close of this account said, "Let us learn to dream, and then perhaps we shall find the truth ... but let us beware of publishing our dreams before they have been put to the proof of the waking understanding."

Lauder William Jones

University of Cincinnati

\section{HOW CAN THE BUREAU OF EDUCATION HELP THE CITY SUPERINTENDENT OF SCHOOLS?}

Among the questions which the Country Life Commission asked in its hearings in the several parts of the United States which it visited was: "In what way can government help in the work of public education?" The question generally evoked two types of answer. The one, 
Government can do nothing; each community must work out its own educational salvation; we must wait for the people to act; they should have the kind of schools that they want, and they should be free to develop educationally as fast or as slowly as they may care to; the whole matter of education should be left to them.

The other type of answer was diametrically opposed to this. It ran:

Government can and must help in the work of education; the nation has done much, but what it has done is all too little compared with what should have been done in promoting school work. $\mathrm{Ve}$ are told-and it is an accepted dictum of American life-that the very existence of the nation depends upon the spread of education among its people. Yet works meet for such a faith have not been produced at Washington. The federal government has consigned its chief interest to the care of a bureau, and has accorded to the titular head of all the educational work of this great country the dignity of a bureau chief. The authority of the United. States Commissioner is even less adequate, for in his last report we read: "The Bureau of Education is peculiarly dependent upon the cooperative spirit among the school officers of the country, for it can only ask for information, which is given voluntarily or not at all." The initiative of local communities, and of the states in some cases, acting as a whole, has produced a variety of educational means, method, plans, systems, institutions, results. The nation spends vast sums in them, but there is too little coordination of all this work, too little wise planning and expert counsel, to accomplish the results which should be accomplished. Government should help by creating an agency to coordinate, encourage, initiate and oversee the educational activity of the entire land. The next great step in the advancement of learning among the American people is to enlarge and safeguard its interests, by giving the Commissioner of Education the rank and the authority of a secretary in the President's cabinet.

There is something to be soid for both these points of view-much more, we think, for the latter than for the former. The interests of education are momentous. Its activities are so chaotic that it must have a pilot to direct its course. Dr. Draper has shown conclusively that a federal educational plan is needed, in order that the national government may more efficiently administer the educa- tional undertakings and responsibility which are now parcelled out among a number of government officers. He has called upon the nation to use the educational office which it has created, and not to neglect and belittle it, but rather to make of it an educational organization worthy of such a people. President Pritchett has called attention to the confusion and false pretense which rub elbows with the standard work of standard institutions in the field of the higher education, and has pointed to a work of standardizing and criticizing and evaluating college and university incorporation, instruction and degree-giving, which must be done by the national government, if it is to be done at all. The national university at Washington is a project which will not down. What is most needed to bring it into being is a national educational agency, with sufficient authority to pass upon the nation's need for such an institution, and adequately to plan for it in whatever form it is needed. Without some guiding authority to shape it, it is certain to be a many-headed compromise, born of committee deliberations, rather than the powerful head of the nation's educational work, which only a responsible authority can make it. In other countries, the interests of education and the fine arts are generally regarded as so completely indivisible that they are committed to the care of a single minister of public instruction and the fine arts. So should it be here, and the same unity of interest should be recognized by educational and artistic forces everywhere throughout the land.

In addition to the administration of the educational work, which is already under the care of the nation, the standardizing and inspecting of the higher instruction of the country, the propagating of a national university in whatever form may be determined as most desirable, and the fostering of the fine arts as a function of government, there remains for the Secretary of Public Instruction and Fine Arts the work of maintaining a national clearing house to further the activities of primary and secondary education throughout the land. Like the Department of Agriculture, it should be a center for the com- 
parative study of school work, and a distributing point of scientific knowledge upon every phase of education. It should be a consulting bureau. Like the Department of Labor, it would assist whenever needed. Strict uniformity of educational practise is certainly far from desirable, but greater uniformity than now obtains would just as certainly be for the best interest of all concerned. The department would be a center of inspiration and leadership for all who are concerned in the educational development of our nation. Besides, its expert help and its expert advice should constantly be available whenever and wherever needed. It should do the work of educational investigation and reporting which the Country life Commission is now doing in regard to the sufficiency of the rural schools. It should plan for their improvement, and should be largely directive in shaping the educational features of such a far-reaching measure as the Davis bill.

As John Stuart Mill pointed out, experimentation, generalization and the formulation of laws for human guidance in the social realm are much more difficult than in the sphere of physical nature; for in social experimenting, the conditions can not be reproduced at will, and the laboratory, which furnishes the facts upon which the inductions of the moral sciences must be based, is the world. Correspondingly urgent is the need for special provision for furnishing such assistance and guidance as a thoroughly furnished central agency of the national government could give to its large and continuing educational activities. That there is here a specific field for governmental activity, the organization of other governments sufficiently proves. The fear of over-centralization through such a department is but a nominal objection to its existence. Agriculture is not centralized or nationalized by being promoted and encouraged by a Secretary of Agriculture. Neither is commerce. But agriculture has profited enormously through the assistance of the department at Washington. Education should profit in the same way. Political control would not interrupt the work of such a de- partment more than it interrupts the work of the other departments of the national government. Indeed, the national government, through its civil-service standards, and its civil-service propaganda, should be able to lend very material assistance in taking the schools out of politics, and in substituting civil-service methods of appointing teachers for the political give and take which, but for assistance from without, bids fair to dominate public school work for some generations to come.

In reply, therefore, to the question, How may the work of the Bureau of Education be expanded so as to aid the city superintendent in his work? I would answer, first, by greatly increasing the power and authority of the office, by promoting the Commissioner of Education to the highest possible position of leadership which the nation can create, and thus giving to school officers of every grade the fullest aid and encouragement which the national government by its example as well as by the thoroughly expert assistance at its command, can render. Not only will the educational arm of the public service be dignified, the esprit de corps of the teaching profession itself will be improved by taking on something of the strength of organization which it has under the governments of the old world. A city superintendent of schools in any one of the larger cities of America is frequently forced to fight an unequal battle against the conditions that war for the undoing of education, simply because there is as yet no sufficient professional support in the land for the educational ideas which he is called upon to defend. No voluntary organization of teachers, no unofficial propaganda for education, no official assistance which a state government is able to render, can have the strength and effectiveness which the national government can command in promoting and intensifying the educational sentiment of the country. The city school systems are called upon to lead in educational invention and readjustment and reorganization of work. Of consulting agencies whose aid they may invoke there are practically none save the officials of other school 
systems, whose eyes are usually turned inward upon their own work, and university departments, whose knowledge of ways and means is by no means complete. The educational office at Washington can be of the greatest service by continuing to do what it is already doing so well, viz., to publish carefully prepared bulletins upon current educational problems. Its recent bulletin upon the apprenticeship system in the United States furnishes a preliminary survey of the field which had to be made before plans for industrial training could be made with knowledge and with certainty. But there are 10,000 questions which school officers will want to ask, and not a few expert opinions which will be required, and some special studies even which they will want made before instruction along industrial lines can be reduced to school terms, and properly launched as a subject of study. There are a myriad of points upon which expert opinions are wanted, such as one may get in medicine or in law, when in need of them, but which education has not as yet formulated a definitely satisfactory means of supplying. For illustration, Should education and school management be a matter of state supervision and control, or should they be left to the care of the community alone? This is the old question of a state system versus local organization of schools, but it is not a moot question, for school systems are being reorganized daily, and it must be that experience and use have shown that these plans are not equally advantageous. Again, what is the proper relation of a city school system to the municipal government of the same territory? The court of appeals of New York State has declared that it is "the settled policy of the state, from an early date, to divorce the business of public education from all other municipal interests or business." Can public education endure unless it maintains this independence of purpose, function and control? And yet the rapidly-growing cities of the country are allowing their school departments to be annexed to the city hall so completely and so rapidly that freedom to do an educational work bids fair to disappear in many parts of the country.
Shall the city board of education fix the amount of money required for school purposes each year, or shall the most corrupt and most inefficient of American institutions, the city government, do it? It makes a vast difference in the effectiveness of a school department how this question is answered, though the total tax rate may remain the same. School departments now segregate their expenses and statistics in one way for the commissioner at Washington, in another for the state superintendent; and sometimes in a third for the city authorities. The Commissioner of Education is attempting to reduce this chaos to order by securing the adoption of standard forms of school reports; but this necessary reform is greatly hindered by the fact that the acceptance and use of such standard forms must be a purely voluntary matter, as the commissioner can not require it. The Bureau of Education could be of very great service by standardizing the different kinds of charges which should be regarded as legitimate claims against the various school funds. As, for instance, What items are proper charges against a public school building fund, and what must be charged to contingent funds? Is new fur.niture put into an old building to be charged to one, or the other? How about the remodeling of buildings to make escape from them easier in case of fire? Must this be classed as repair work, or as building? Neither the laws nor the decisions of the various states are quite specific upon such points. The need for uniformity of practise is not so much that the proper charges may be made, but that, having been made, caviling critics may not be able successfully to attack them. There is a national municipal system of bookkeeping which unofficially is doing for cities what a similar system worked out by the Bureau of Education should do for the accounting of the schools. What are the health measures which a city school system should undertake? How can it best proceed to enforce the compulsory education law, and bring all its children into school? What responsibility should it assume for the child-labor law? How can it assist in preventing juvenile delinquency? What part 
can it take in the work of promoting the general welfare of children? Besides there are ever with us the great questions of the course of study and methods of learning-the what and the how of teaching. In collecting and reporting the more successful experiments which are being made in the schools of any part of the world, the Bureau of Education is doing an incalculable service in making wellestablished scientific formulations of education possible. Special help is needed in the study of ways and means for the teaching of morality and the elements of law that no child may grow up without being well grounded in the knowledge of the fundamental relations of human beings. The office of the Commissioner of Education has always been wisely and ably administered. It has been of immense assistance in promoting education in the United States. It is reaching out to a larger work. The time is ripe for it. But to do it, the Bureau of Education must have larger appropriations, more experts, and above all, a much larger authority and function in the service of the nation.

Los Angetes, CaL.

WATER VAPOR IN THE ATMOSPHERE OF THE PLANET MARS ${ }^{1}$

As expedition from the Lick Observatory, University of California, was recently sent to the summit of Mt. Whitney, the highest point of land in the United States, through the private generosity of Regent Wm. H. Crocker. It had for its purpose to study the question of water vapor in the atmosphere of the planet Mars. The instruments consisted of a sixteen-inch horizontal reflecting telescope and a suitable spectroscope. The observations, made on the nights of September 1 and 2, were mainly photographic.

Water vapor in the atmosphere of any planet causes dark bands to be formed at certain definite positions in the spectrum of that planet; conspicuous bands if the water vapor is abundant; inconspicuous bands if the quan-

${ }^{1}$ Statement by Director W. W. Campbell, of the Lick Observatory, prepared for the Associated Press. tity is slight, as this, the only method known, is not a sensitive one.

The observer of Mars must look up through the earth's atmosphere; and the great quantity of water vapor in our atmosphere, if the observer is near sea level or at ordinary altitudes, blots out the effect of any Martian vapor, making a solution of the problem impossible. By ascending Mt. Whitney, altitude 14,501 feet, the Crocker expedition placed itself above probably four fifths or more of the earth's water vapor. Further, the air on Mt. Whitney was astonishingly dry during the time of the observations. With barometer $17 \frac{2}{3}$ inches, air temperature 29 degrees Fahrenheit, and wet thermometer 17 degrees, students of the atmosphere will recognize that the observers of Mars were looking through remarkably little terrestrial water vapor. Even this small quantity would be almost fatal to success if we did not have a fairly satisfactory method of eliminating its effects, as follows: Our moon has no appreciable atmosphere. The lunar and Martian spectra will be affected alike by the water vapor in the earth's atmosphere. These spectra are photographed, one immediately after the other while the conditions in our atmosphere remain unchanged, and with the moon and Mars at the same altitude above the horizon so that their rays traverse equal paths in our atmosphere. If the vapor bands in the Martian spectrum are found to be stronger than in the lunar spectrum, Mars has water vapor in considerable quantities. If the bands in the two spectra are equally strong, water vapor on Mars does not exist in sufficient quantities to be detected by the spectroscopic method. The latter condition was found to exist, when this method was applied under the superlatively favorable conditions existing on Mt. Whitney. Both spectra were photographed when Mars and the moon were near the horizon, again when they were at medium altitudes, and finally when they were 49 degrees above the horizon. The best vapor band, technically called "a," was faint in both spectra when the bodies were low, fainter when the bodies were higher, and very faint when the bodies were at their highest; but for equal altitudes the "a" bands in the Martian and 